\title{
SIMULASI UNJUK KERJA DISCRETE WAVELET TRANSFORM (DWT) DAN DISCRETE COSINE TRANSFORM (DCT) UNTUK PENGOLAHAN SINYAL RADAR DI DAERAH YANG BER-NOISE TINGGI
}

\author{
Raisah Hayati * dan Rahmadi Kurnia** \\ *Jurusan Teknik Elektro, Politeknik Negeri Lhokseumawe \\ Email :raipnl@gmail.com \\ **Fakultas Teknik, Jurusan Teknik Elektro, UNAND \\ Email : rahmadikurnia@ft.unand.ac.id
}

\begin{abstract}
Abstrak-Pendeteksian sinyal yang lemah dan penentuan lokasi sasaran adalah dasar dan masalah penting dalam sistem radar. Performansi radar dapat ditingkatkan dengan peningkatan rasio sinyal terhadap noise (signal-to-noise ratio /SNR) pada receiver. Pada penelitian ini, akan digambarkan suatu algoritma dalam pengolahan sinyal radar, yaitu untuk mengekstrak sinyal sasaran yang dinginkan untuk daerah yang ber-noise. Discrete Cosine Transform (DCT) dan Discrete Wavelet Transform (DWT) merupakan suatu fungsi matematika yang paling sukses dalam bidang pengolahan sinyal dalam dua puluh tahun terakhir ini. Pada penelitian ini dilakukan simulasi sinyal dengan menggunakan $D C T$ dan $D W T$, menganalisa performansinya dalam pengolahan sinyal radar. Pengolahan sinyal dengan metode $D W T$ akan dianalisa dan dibandingkan performansinya dengan mother wavelet Haar, Daubechies-12, Coiflet-5 dan Symlet-8. Sedangkan pengolahan sinyal dengan metode DCT akan dianalisa dan dibandingkan dengan beberapa fungsi window yang digunakan dalam pembatasan sinyal. Fungsi window berpengaruh dalam resolusi (pemisahan sinyal) dalam domain frekuensi yang merupakan output dari hasil DCT. Fungsi window yang diuji adalah Rectangular, Hamming, Hanning dan Dolph-Chebyshev. Dari hasil simulasi dan analisis diperoleh, untuk pengujian mother wavelet pada metode DWT, mother wavelet Daubechies-12 dan Symlet-8 menghasilkan performansi terbaik dan mother wavelet Haar menghasilkan performansi paling jelek. Rasio sinyal terhadap noise tertinggi yang diperoleh dari penggunaan mother wavelet Daubechies-12 adalah 32,0603 dB dan untuk penggunaan mother wavelet Symlet- 8 diperoleh rasio sinyal terhadap noise yang paling tinggi adalah 32,6589 dB. Dan untuk penggunaan mother wavelet Haar, rasio sinyal terhadap noise yang paling tinggi adalah 14,6692 dB. Dan untuk pengujian fungsi window pada DCT, window Dolph-Chebyshev menghasilkan performansi terbaik, yaitu menghasilkan resolusi pemisahan komponen-komponen frekuensi sinyal yang paling baik. Analisis sinyal pantulan yang diterima kembali oleh radar dengan menggunakan $D W T$ memberikan unjuk kerja (performansi) yang lebih baik dibandingkan dengan menggunakan DCT, khususnya dalam menghilangkan noise.
\end{abstract}

Kata Kunci : Radar, DWT, DCT, window dan noise.

\begin{abstract}
Detection of low signal and determination target locations is the basis and important in the system radar. Performance of radar can enhanced with enhancement signal-to-noise ratio in the receiver. In this research, will show a algorithm in radar signal processing, that is for extract the signal target in the place of noise. Discrete Cosine Transform (DCT) and Discrete Wavelet Transform (DWT) is the success full mathematic function in the signal processing in the last twenty years. In this research will simulate signal with DCT and DWT, analysis his performance in radar signal processing. DWT signal processing will analysis and compare with mother wavelet Haar, Daubechies-12, Coiflet-5 and Symlet-8. DCT signal processing will analysis and compare with same of window function with use in signal restrictions. Window function have influence signal resolution in domain frequency. Window function that use in this research Rectangular, Hamming, Hanning and Dolph-Chebyshev. The result of simulation and analysis Is: mother wavelet with DWT, wavelet Daubechies-12 and Symlet-8 give the best performance and mother wavelet Haar give bad performance. Wavelet Daubechies-12 give the biggest signal to noise ratio that is $32,0603 \mathrm{~dB}$. Mother wavelet Symlet- 8 give 32,6589 dB. Mother wavelet Haar give 14,6692 dB. Testing window function DCT, window Dolph-Chebyshev give the best performance, with give the best separation of signal. Analysis of signal reflection that accept of radar give the result that DWT is better performance than DCT in breaking of noise.
\end{abstract}

Keywords: Radar, DWT, DCT, window dan noise. 


\section{PENDAHULUAN}

Radar (Radio Detection And Ranging) adalah suatu instrumen yang meradiasikan geombang-gelombang elektromagnetik ke angkasa dan mendeteksi kehadiran dan lokasi sasaran dari gelombang yang dipantulkan. Kekuatan sinyal pantulan yang diterima kembali oleh radar bervariasi, tergantung pada jarak radar terhadap sasaran dan juga tergantung pada cross section sasaran radar. Radar cross section digunakan untuk menggambarkan jumlah pantulan daya hambur dari suatu sasaran ke arah radar. Pendeteksian untuk sinyal-sinyal yang lemah merupakan permasalahan dasar dan penting pada sistem radar. Salah satu solusinya yaitu dengan meningkatkan kemungkinan pendeteksian untuk obyek-obyek yang kecil dengan jarak yang jauh, yaitu dengan menaikkan SNR (Signal to Noise Ratio) pada receiver output umumnya dilakukan dengan integrasi pulsa, dimana sinyal yang diterima terdiri dari sejumlah interval perulangan pulsa (pulse repetition intervals- $P R I$ ) sebelum atau sesudah pendeteksian. Akan tetapi, integrasi pulsa memerlukan sejumlah pulsa untuk meningkatkan SNR pada receiver output. Untuk radar dengan fasilitas fast scanning, jumlah pulsa yang diperlukan untuk satu objek tidak memenuhi untuk membentuk integrasi pulsa.

Analisis Wavelet dan Discrete Cosine Transform (DCT) merupakan fungsi matematika yang paling sukses dalam bidang pengolahan sinyal dalam dua puluh tahun terakhir ini. DWT menggunakan filter wavelet tertentu untuk membagi data ke dalam frekuensi yang berbeda atau komponenkomponen skala, dan selanjutnya menganalisis masing-masing komponen dengan suatu resolusi yang sesuai dengan skalanya. $D W T$ sangat ideal untuk mengekstrak informasi dari sinyal stasioner atau transient. Jadi DWT filter bank dapat digunakan untuk memisahkan band-band frekuensi yang berbeda, tanpa pengetahuan eksplisit dari parameter radar seperti PRF (Pulsa Repetition Frekuensi) atau frekuensi pengulangan pulsa. Semua fungsi yang digunakan dalam Discrete Wavelet Transform (DWT) diturunkan dari mother wavelet. Sehingga mother wavelet juga akan menentukan karakteristik dari transformasi wavelet yang dihasilkan.
Discrete Cosine Transform (DCT) adalah sebuah teknik untuk mengubah sebuah sinyal menjadi komponen frekuensi dasar. Discrete Cosine Transform (DCT) berhubungan erat dengan Discrete Fourier Transform (DFT), sehingga menjadikan data direpresentasikan dalam komponen frekuensi. Hasil yang diperoleh dari pengolahan sinyal menggunakan Discrete Cosine Transform (DCT) dianalisa dan dibandingkan dengan hasil yang diperoleh dari pengolahan sinyal menggunakan Discrete Wavelet Transform (DWT).

Beberapa peneliti telah secara intensif mempelajari kinerja transformasi wavelet pada pengolahan sinyal radar, diantaranya Aly, (2006)[1] yang mengkombinasikan analisis wavelet packet dan higher-order-statistics (HOS) untuk mengekstrak dan menentukan lokasi suatu $R F$ radar pulse dari daerah yang ber-noise. Penelitian lain dilakukan oleh Ellonen, (2008)[2] yang mengimplementasikan Discrete Wavelet Transform (DWT) pada Filter Bank. Filter bank tersebut dipergunakan untuk pemfilteran chaff clutter, yaitu sejenis clutter terdistribusi yang merupakan buatan manusia, atau disebut juga passive jamming. Dan penelitian lain yang dilakukan oleh Ellonen, (2006)[3] adalah meng- implementasikan Discrete Wavelet Transform (DWT) pada filter bank untuk pemfilter-an rain clutter (interferensi yang berasal dari hujan) dari sinyal pantulan radar. Pada penelitian tersebut dibandingkan antara $D W T$ filter bank dan Fourier filter bank (FFT). Setyawan, (2006)[4] melakukan penelitian Simulasi Filter Digital FIR (Finite Impulse response) dengan menggunakan DCT (Discrete Cosine Transform). Pada penelitian tersebut pemfilteran FIR dengan DCT dibandingkan dengan $F F T$ dengan metode yang sama.

Pada penelitian ini penulis akan menggunakan dua metode yaitu, Discrete Wavelet Transform (DWT) dan Discrete Cosine Transform (DCT) untuk pengolahan sinyal radar untuk pem-filter-an noise dan interferensi. Tujuan dari penelitian ini adalah menganalisis unjuk kerja Discrete Wavelet Transform (DWT) dan Discrete Cosine Transform (DCT) untuk memisahkan sinyal yang diterima kembali oleh radar yang terdiri dari noise dan interferensi dan mendeteksi sinyal sasaran yang diinginkan, khususnya 
untuk sinyal-sinyal yang lemah dan tertutupi oleh noise dan interferensi. Hipotesis sementara, menyatakan bahwa DWT lebih handal digunakan dalam pemfilteran noise, sedangkan $D C T$ lebih sesuai untuk pem-filteran interferensi (Clutter).

\section{DASAR TEORI}

\subsection{PENGOLAHAN SINYAL RADAR}

Blok diagram sistem radar yang sederhana ditunjukkan pada Gambar 1. Sinyal radio yang berupa gelombang elektromagnetik dibangkitkan oleh transmitter, dan dipancarkan melalui antena ke angkasa. Sinyal yang dipancarkan tersebut akan berpropagasi melalui atmosfer pada kecepatan dekat dengan kecepatan cahaya, yaitu memiliki medan listrik dan medan magnetik pada rasio $120 \pi(\approx 377$ $\Omega$ ), yang merupakan impedansi atmosfer atau ruang bebas (free space). Apabila sinyal-sinyal yang dipancarkan menemukan suatu obyek dengan karakteristik impedansi yang berbeda dari medium tersebut, sinyal akan membentur obyek tersebut, dan terjadi pantulan. Sinyal pantulan yang diperoleh kembali oleh radar terdiri dari gema sasaran, noise, dan interferensi. Dan tujuan utama pengolahan sinyal radar adalah[5]: menekan semua sinyal lainnya selain gema dari sasaran yang diinginkan sehingga sasaran yang dinginkan mudah dideteksi, dan mengumpulkan informasi tentang tingkah laku sasaran, termasuk posisinya, kecepatan dan karakteristiknya.

Sinyal yang dibangkitkan oleh radar dapat berupa gelombang kontinyu sinusoidal dan pulsa[6]. Untuk Continuous Wave (CW) Radars menggunakan grelombang kontinyu, yang dapat dimodelkan dengan gelombang sinus murni, yaitu $\cos 2 \pi f_{0} t$. Untuk gema sinyal yang berasal dari sasaran tetap (stasioner) atau interferensi (clutter) stasioner spektrumnya akan terkonsentrasi pada $f_{0}$. Frekuensi pusat untuk sinyal-sinyal yang berasal dari sasaran bergerak atau interferensi (clutter) dari sasaran bergerak akan bergeser sebesar $f_{d}$. $f_{d}$ adalah pergeseran Doppler. Pergeseran Doppler adalah perbedaan frekuensi antara gema yang diterima dan sinyal yang dikirim yang disebabkan oleh gerakan sasaran terhadap radar. Pergeseran
Doppler dapat digunakan untuk mengukur kecepatan suatu sasaran dan dapat digunakan untuk memisahkan sasaran-sasaran yang terjadi pada waktu yang sama, tetapi bergerak dengan kecepatan yang berbeda. Jadi pergeseran Doppler dapat digunakan untuk memisahkan gema dari sasaran bergerak dengan interferensi (clutter). Pergeseran Doppler tersebut diperoleh berdasarkan persamaan[5]:

$$
f_{d}=f_{t}\left[\frac{1+\frac{V_{R}}{c}}{1-\frac{V_{R}}{c}}-1\right]
$$

di mana :

$$
\begin{aligned}
& \mathrm{f}_{\mathrm{t}}: \text { frekuensi transmisi } \\
& \mathrm{V}_{\mathrm{R}} \quad: \text { kecepatan radial sasaran terhadap } \\
& \text { radar } \\
& \mathrm{c} \quad \text { : kecepatan propagasi }
\end{aligned}
$$

Dengan mengasumsikan $\mathrm{V}_{\mathrm{R}}<<\mathrm{c}$

$$
f_{d} \approx 2 f_{t} \frac{V_{R}}{c}
$$

Sedangkan untuk pulsed radars, radar mentransmisikan dan menerima sederetan pulsa. Range dapat diekstrak berdasarkan perbedaan waktu (delay) antara pulsa yang dikirim dengan pulsa yang diterima. Untuk pengukuran frekuensi Doppler dapat dilakukan dengan cara, yaitu: jika pengukuran range yang akurat tersedia antara dua pulsa berurutan, frekuensi Doppler dapat diekstrak dari Rate range[6]:

$$
R=\frac{\Delta R}{\Delta t}
$$

Di mana :

$\mathrm{R}$ : Rate Range

$\Delta \mathrm{R}$ : Range antara dua pusa berurutan.

$\Delta \mathrm{t}$ : delay (waktu)

Pendekatan tersebut dapat bekerja baik, sepanjang range tidak berubah drastis dalam interval $\Delta \mathrm{t}$. Cara lain dapat dilakukan dengan Filter Bank Doppler. Filter Bank Doppler digital biasanya diimplementasikan dengan menggunakan Discrete Fourier Transform (DFT) seperti diperlihatkan pada Gambar 2. 


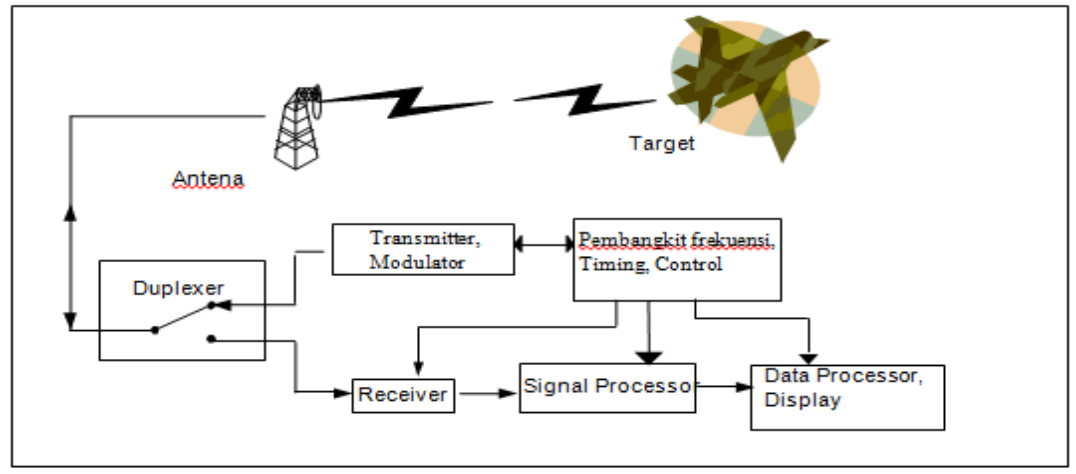

Gambar 1. Blok diagram prinsip kerja radar[5]

DFT merupakan teknik utama analisis spektrum. Radar menggunakan analisis spektrum untuk memisahkan gelombang pantulan dari sasaran yang diinginkan dengan gelombang pantulan dari sasaran yang tidak diinginkan atau interferensi. Hasil output dari Filter Bank Doppler tersebut adalah bin-bin Doppler. Bin Doppler adalah bandwidth diskrit yang di dalamnya gema sasaran diproses.

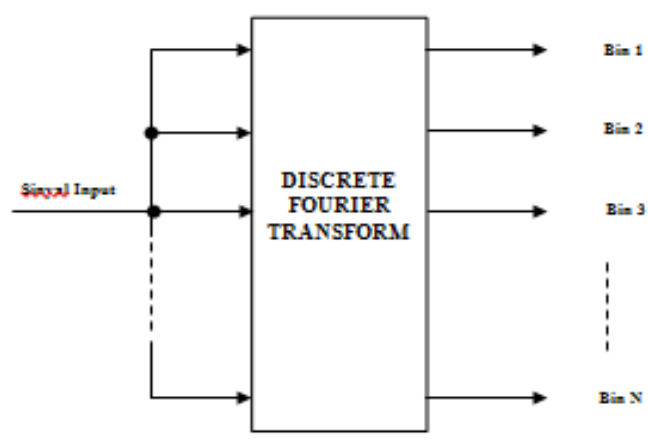

Gambar 2. Filter Bank Digital[5].

Radar menerima beberapa bentuk interferensi, yang menyulitkan pendeteksian dan proses pengukuran sasaran. Lima jenis interferensi dasar, yaitu noise, clutter, ECM, EMI dan spillover. Salah satu peranan pengolahan sinyal adalah untuk menekan sinyal-sinyal interferensi tersebut.

Noise, diakibatkan oleh gerakan acak partikel-partikel secara elektrik yang terjadi pada semua temperatur di atas nol absolut, tidak dapat dihindari yang dibangkitkan pada receiver radar, dengan jumlah kecil juga dari antena dan jalur transmisi, dan dari sumber-sumber eksternal terutama matahari.
Clutter adalah gema sinyal yang tidak diinginkan dari laut, tanah, dan cuaca. Clutter adalah sebuah sinyal gema real yang biasanya ditekan berdasarkan pergeseran Doppler yang berbeda dari sasaran yang diinginkan.

ECM (Electronic countermeasures) atau jamming adalah interferensi yang sengaja dibangkitkan dalam suatu usaha untuk mengacaukan pendeteksian gema-gema sasaran.

$\square$ EMI (Electronic interference) adalah interferensi yang tidak disengaja dari sumber-sumber yang berdekatan, seperti radar-radar lain, sistem-sistem komunikasi dan jammer-jammer yang berdekatan.

$\square$ Spillover terjadi terutama sekali pada gelombang kontinyu $(\mathrm{CW})$ radar, dan disebabkan oleh pengoperasian transmitter dan receiver secara serentak. Ini adalah kebocoran dari transmitter pada receiver.

\subsection{Discrete Wavelet Transform (DWT).}

Transformasi sinyal merupakan bentuk lain dari penggambaran sinyal yang tidak mengubah isi informasi dalam sinyal tersebut. Transformasi wavelet memiliki dua seri dalam pengembangannya, yaitu: Continous Wavelet Transform (CWT) dan Discrete Wavelet Transform (DWT). Semua fungsi yang digunakan dalam transformasi $C W T$ dan $D W T$ diturunkan dari mother wavelet melalui translasi/pergeseran dan penskalaan/kompresi. DWT dan koefisiennya didefinisikan sebagai:

$W_{f}(s, \tau)=\left\langle f(t), \psi_{s, \tau}(t)\right\rangle=\int_{R} f(t) \psi_{s, \tau}^{*}(t) d t \ldots \ldots$ 
Dimana $f(t)$ adalah sinyal dalam domain waktu, $\psi_{s, \tau}$ adalah wavelet dan $*$ menotasikan konjugasi kompleks.

Ketika sinyal $f(t)$ dilewatkan melalui satu set filter yang ditentukan oleh suatu wavelet family, dapat diperoleh output yaitu koefisien DWT. Koefisien-koefisien tersebut menggambarkan kandungan sinyal dalam domain time-scale. Pada transformasi wavelet two-channel diskirt sinyal dipisahkan dalam komponen lowpass dan highpass[7] dapat dilihat pada Gambar 3, h(k) adalah lowpass filter sebagai scaling filter dan $\mathrm{g}(\mathrm{k})$ adalah highpass filter sebagai wavelet filter.

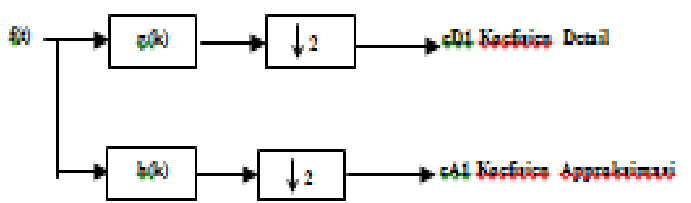

Gambar 3. Proses Transformasi Wavelet[7].

Langkah selanjutnya adalah mentransformasi- kan mentransformasikan koefisien Approksimasi cA1 menjadi dua bagian menggunakan skema yang sama, menggantikan cA1 dan menghasilkan cA2 dan $\mathrm{cD} 2$, dan seterusnya. Untuk level yang lebih tinggi, koefisien Approksimasi didekomposisi lagi menjadi koefisien Approksimasi dan koefisien Detail pada level selanjutnya. Pada Gambar 4 menggambarkan dekomposisi filter banks DWT pada level 3.

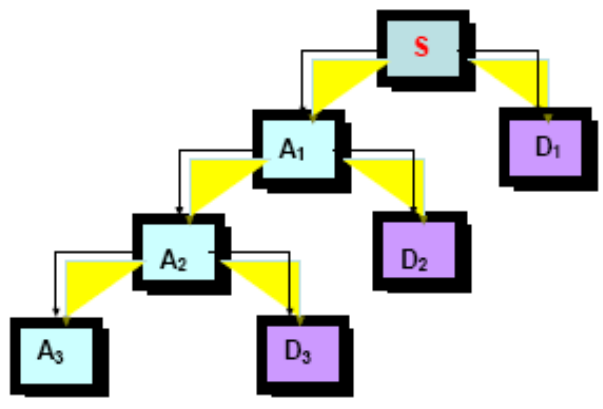

Gambar 4. Dekomposisi wavelet untuk sinyal s pada level 3[8].

Proses dekomposisi terdiri dari proses penyaringan dan downsampling secara horizontal menggunakan LPF (Low Pass Filter) dan HPF (High Pass Filter). Untuk mendapatkan kembali sinyal asli dari komponen-komponen detail dan aproksimasi, maka dilakukan proses rekonstruksi. Proses rekonstruksi ini bertujuan untuk menggabungkan semua komponen detail dengan komponen aproksimasi. Proses rekontruksi digambarkan pada Gambar 5[7].

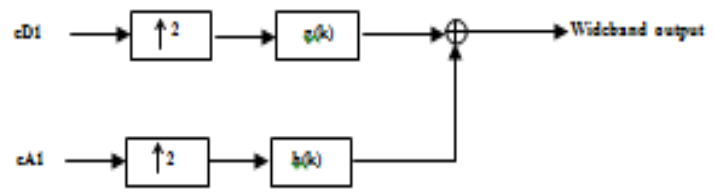

Gambar 5. Proses Transformasi Invers Wavelet[7].

Mother wavelet merupakan fungsi dasar yang digunakan dalam transformasi wavelet. Karena mother wavelet menghasilkan semua fungsi wavelet yang digunakan dalam transformasi melalui translasi dan penskalaan, maka mother wavelet juga akan menentukan karakteristik dari transformasi wavelet yang dihasilkan. Oleh karena itu, perlu pencatatan secara teliti terhadap penerapan wavelet dan pemilihan yang tepat terhadap mother wavelet harus dilakukan agar dapat menggunakan transformasi wavelet secara efisien. Mother wavelet yang akan diuji dalam penelitian ini adalah mother wavelet Haar, Daubechies, Coiflet, dan Symlet.

\subsection{Discrete Cosine Transform (DCT).}

Discrete Cosine Transform (DCT) atau Transformasi Cosinus Diskrit adalah model Transformasi Fourier yang dikenakan pada fungsi diskrit dengan hanya mengambil bagian cosinus dari eksponensial kompleks, dan hasilnya juga diskrit. DCT merupakan salah satu transformasi yang penting dalam pengolahan sinyal digital. DCT mengubah fungsi dari domain waktu ke domain frekuensi. DCT pertama kali diperkenalkan oleh Ahmad Natarajan dan Rao pada tahun 1974. Discrete Cosine Transform dari sederet $n$ bilangan real $f(n)$, adalah $F(k), k=1, \ldots, N$, dirumuskan sebagai berikut:

$$
\begin{aligned}
& F(k)=\sum_{n-1}^{N} f(n) \cos (2 \pi n k / N) \\
& \mathrm{k}=1, \ldots, \mathrm{N}
\end{aligned}
$$

Berbeda dengan Discrete Fourier Transform (DFT) yang hasilnya berupa 
variabel kompleks dengan bagian real dan imaginer, maka hasil DCT hanya berupa real tanpa ada imaginer. Hal tersebut banyak membantu karena dapat mengurangi perhitungan. Dalam $D C T$ nilai magnitude adalah hasil dari $D C T$ itu sendiri dan tidak diperlukan phase.

\section{METODE PENELITIAN}

Pada penelitian ini, akan dianalisis unjuk kerja dua metode untuk menganalisis sinyal, yaitu Discrete Wavelet Transform (DWT) dan Discrete Cosine Transform (DCT), yang akan diaplikasikan pada pengolahan sinyal radar. Unjuk kerja (performance) dari suatu sistem komunikasi dinyatakan sebagai rasio sinyal terhadap noise $(\mathrm{S} / \mathrm{N})[9]$. Langkah kerja secara umum adalah sebagai berikut:

1. Memodelkan beberapa kondisi sinyal input, yang terdiri dari sinyal pantulan dari sasaran yang diinginkan, interferensi dan noise.

2. Menganalisis sinyal input tersebut dengan menggunakan metode Discrete Wavelet Transform (DWT) dan Discrete Cosine Transform (DCT).

3. Menganalisis unjuk kerja, sinyal output dari $D W T$ dan $D C T$. Dalam menganalisis unjuk kerja, parameter yang diukur adalah rasio sinyal terhadap noise, dan akan ditampilkan plot dalam kawasan frekuensi untuk pemisahan komponen-komponen frekuensi Doppler suatu sinyal. Rasio sinyal terhadap noise dihitung berdasarkan persamaan[10]:

$$
S N R_{d B}=10 \log _{10} \frac{\sigma_{x}^{2}}{\sigma_{e}^{2}}
$$

$\sigma_{x}^{2}$ adalah daya dari $\mathrm{x}[\mathrm{n}]$, dimana $\mathrm{x}[\mathrm{n}]$ adalah sinyal yang belum terdistorsi oleh noise. $\sigma_{e}^{2}$ adalah daya dari $\mathrm{e}[\mathrm{n}]$ yang merupakan noise yang tersisa setelah dilakukan pemrosesan, yaitu selisih antara sinyal dari output sistem setelah dilakukan pemrosesan dengan $D W T$ dan $D C T$ dengan sinyal yang belum terdistorsi $\mathrm{x}[\mathrm{n}]$.

4. Langkah selanjutnya adalah analisis dari hasil unjuk kerja $D W T$ dan $D C T$ pada pengolahan sinyal radar, dan penulisan kesimpulan.

Dalam analisis sinyal menggunakan DWT langkah-langkahnya adalah sebagai berikut:

1. Setelah sinyal $s(n)$ dibatasi dari $n=0$ sampai N-1, langkah selanjutnya membentuk dekomposisi sinyal menggunakan transformasi wavelet. Keluarga wavelet yang digunakan pada penelitian ini adalah: Wavelet Haar, Wavelet Daubechies, Wavelet Coiflet, dan Wavelet Symlet.

2. Langkah selanjutnya menetapkan threshold dari masing-masing koefisien. Pemisahan noise dilakukan dengan Thresholding. Dan yang terakhir adalah merekontruksi sinyal dari koefisienkoefisien yang tersisa.

3. Langkah terakhir memplot spektrum sinyal hasil rekontruksi.

Langkah analisis sinyal menggunakan DCT sebagai berikut:

1. Setelah sinyal $s(n)$ dibatasi dari $n=0$ sampai N-1, selanjutnya sinyal tersebut dikalikan dengan fungsi window. Fungsi window yang digunakan adalah Rectangular, Hamming, Hanning dan Dolph-Chebyshev.

2. Langkah selanjutnya adalah menggunakan persamaan (5) untuk mengubah sinyal $\mathrm{s}(\mathrm{n})$ tersebut menjadi koefisien-koefisien $D C T$. Hasil yang diperoleh dari $D C T$ adalah komponen-komponen frekuensi dari sinyal $\mathrm{s}(\mathrm{n})$.

\section{HASIL DAN ANALISIS}

Pengujian dilakukan pada beberapa model kondisi sinyal input, keseluruhan model kondisi sinyal input yang akan diuji terletak pada bin range yang sama dan dapat dipisahkan berdasarkan analisis Doppler jika kecepatannya berbeda.

Untuk model kondisi sinyal input yang pertama, dua sinyal dengan frekuensi Doppler 10 cycles dan 16 cycles. Perioda sinyal adalah 100 detik dan jumlah titik pencuplikan adalah 1000, sinyal yang frekuensi Doppler-nya 10 
cycles merupakan sinyal interferensi dengan amplitudo 50 dan sinyal yang frekuensi Doppler-nya 16 cycles merupakan sinyal dari sasaran yang diinginkan dengan amplitudo 1 . Plot sinyal dan spektrumnya dapat dilihat pada Gambar 8.
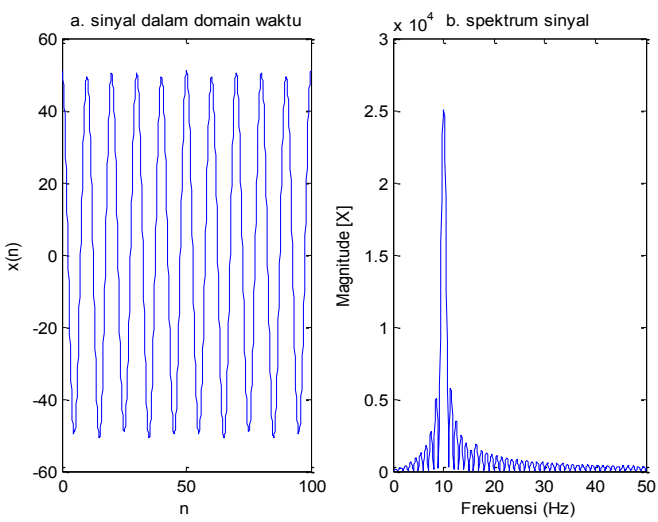

Gambar 6. Model kondisi sinyal input yang pertama dan spektrumnya.

Spektrum full recontruction dari output DWT, dengan menggunakan mother wavelet Haar, Daubechies-12, Coiflet-5 dan Symlet-8 dapat dilihat pada Gambar 7, 8, 9, dan 10.

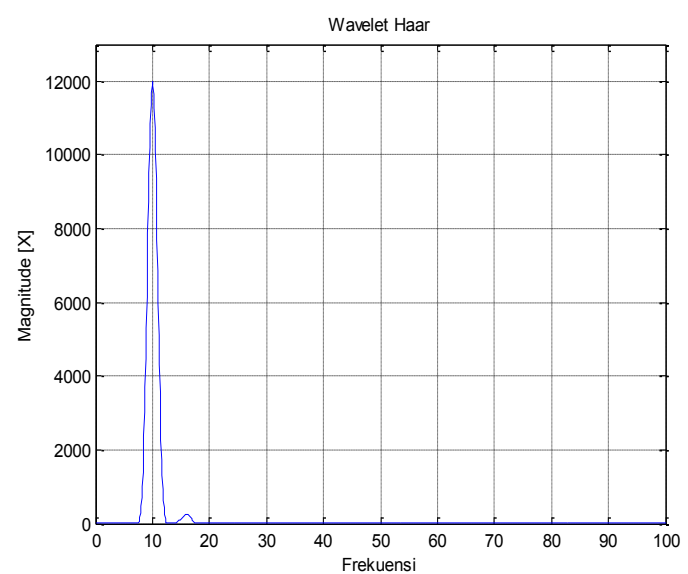

Gambar 7. Spektrum DWT dengan mother Wavelet Haar untuk model kondisi sinyal input yang pertama.

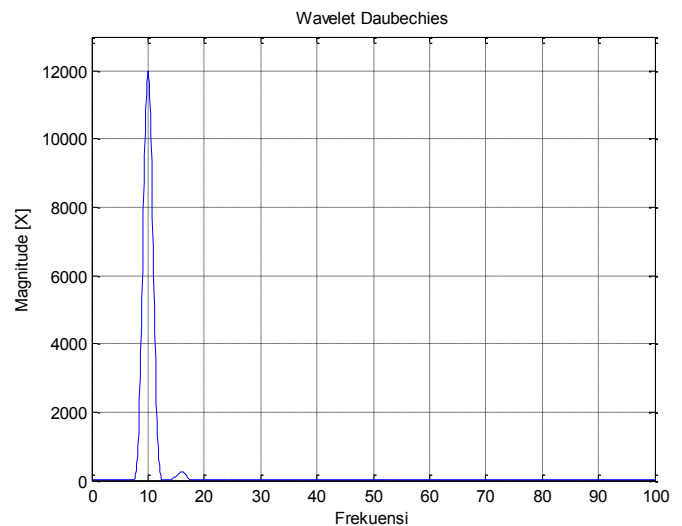

Gambar 8. Spektrum DWT dengan mother Wavelet Daubechies untuk model kondisi sinyal input yang pertama.

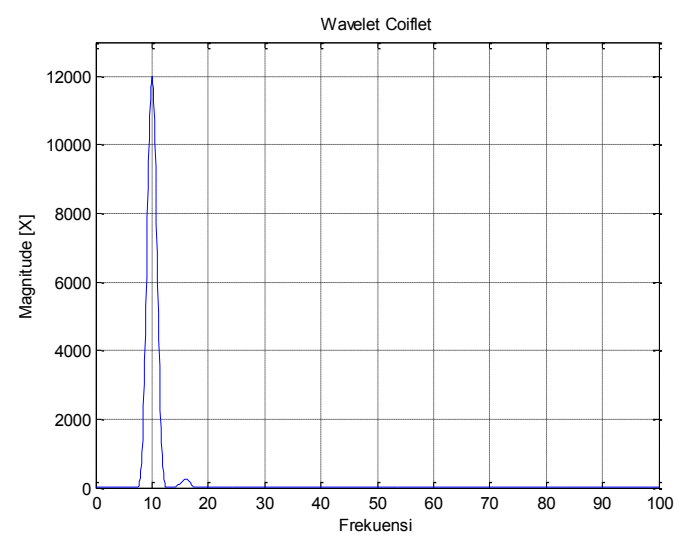

Gambar 9. Spektrum DWT dengan mother Wavelet Coiflet untuk model kondisi sinyal input yang pertama.

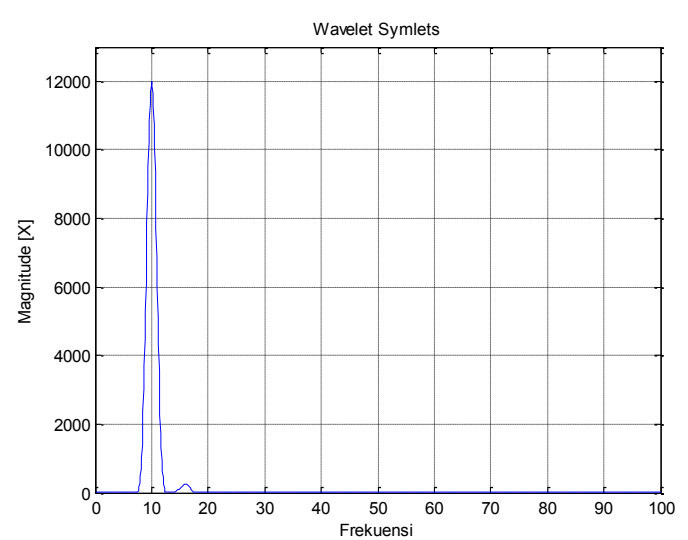

Gambar 10. Spektrum DWT dengan mother Wavelet Symlet untuk model kondisi sinyal input yang pertama. 
Dari plot spektrum Gambar 7, 8, 9 dan 10 untuk keempat mother wavelet yang diuji menghasilkan gambar yang sama, sinyal pantulan dari sasaran yang diinginkan terpisah sempurna dari sinyal interferensi, sehingga sasaran dapat dideteksi meskipun amplitudonya sangat kecil dibandingkan sinyal interferensi.

Pada pungujian sinyal dengan menggunakan $D C T$, akan diuji beberapa fungsi window yang digunakan dalam pembatasan sinyal, fungsi window yang akan diuji adalah Rectangular, Hamming, Hanning dan Dolph Chebyshev. Fungsi window tersebut berpengaruh dalam resolusi sinyal (pemisahan sinyal) dalam domain frekuensi yang merupakan output dari hasil DCT. Hasil simulasi untuk model kodisi sinyal input yang pertama menggunakan $D C T$ dapat dilihat pada Gambar 11, 12, 13 dan 14.

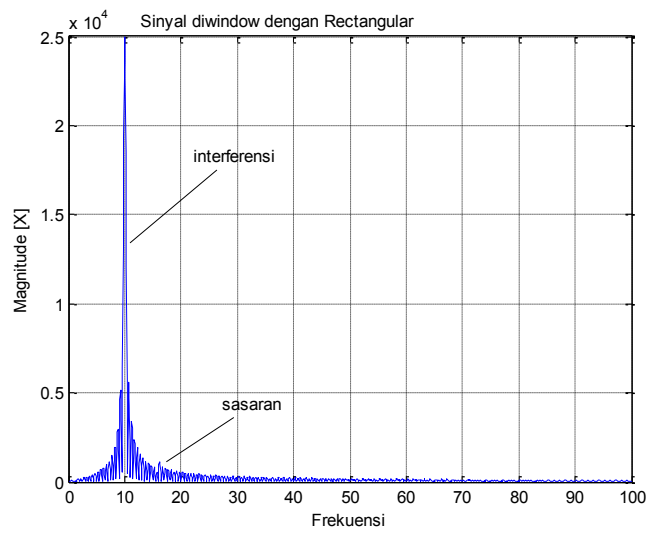

Gambar 11. Spektrum DCT dengan window Rectangular untuk model kondisi sinyal input yang pertama.

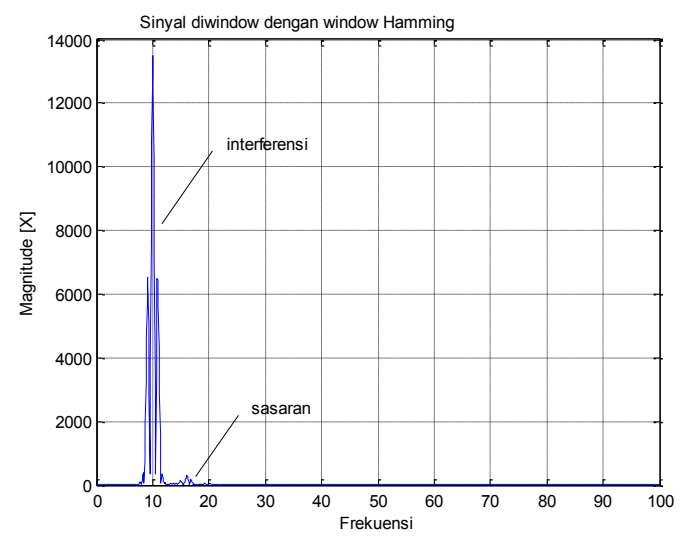

Gambar 12. Spektrum DCT dengan window Hamming untuk model kondisi sinyal input yang pertama.

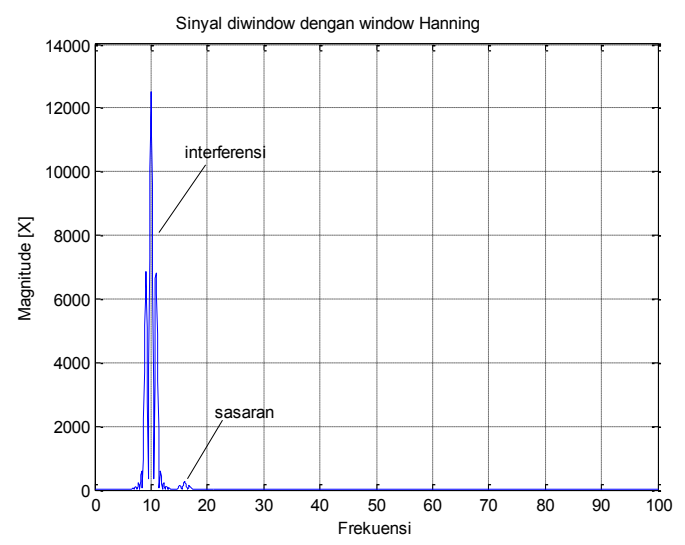

Gambar 13. Spektrum DCT dengan window Hanning untuk model kondisi sinyal input yang pertama.

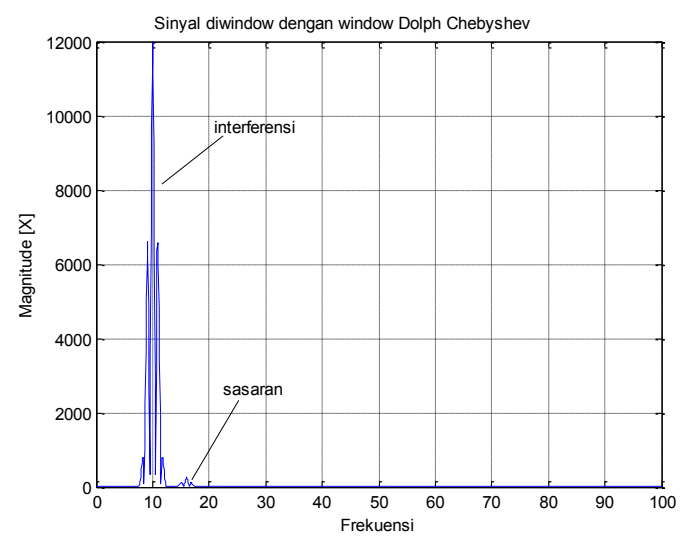

Gambar 14. Spektrum DCT dengan window Dolph-Chebyshev untuk model kondisi sinyal input yang pertama.

Dari Gambar 11 terlihat bahwa, untuk penggunaan window Rectangular, sinyal sasaran yang diinginkan tertutupi sepenuhnya oleh bocoran spektrum (spektrum leakage) dari sinyal interferensi, sehingga sinyal dari sasaran yang diinginkan sangat sulit dideteksi. Dari Gambar 11 jelas terlihat kegagalan window Rectangular untuk memisahkan komponen-komponen frekuensi suatu sinyal. Untuk penggunaan window Hamming, Hanning dan Dolph-Chebyshev, terlihat sinyal dari sasaran yang diinginkan terpisah sempurna dari sinyal interferensi, sehingga sasaran dapat dengan mudah dideteksi, tetapi window Dolph-Chebyshev memberikan hasil 
yang paling baik dalam pemisahan komponenkomponen frekuensi suatu sinyal.

Untuk model kondisi sinyal input yang kedua, sinyal input terdiri dari sinyal dari sasaran yang diinginkan, interferensi dan noise. Dua sinyal dengan frekuensi Doppler 10 cycles dan 16 cycles. Perioda sinyal adalah 100 detik dan jumlah titik pencuplikan adalah 1000, sinyal yang frekuensi Doppler-nya 10 cycles merupakan sinyal interferensi dengan amplitudo 50 dan sinyal yang frekuensi Doppler-nya 16 cycles merupakan sinyal dari sasaran yang diinginkan dengan amplitudo 1 . Noise yang digunakan adalah Gaussian White Noise dengan daya $20 \mathrm{~dB}$. Noise tersebar secara merata pada semua bin Doppler. Plot sinyal dan spektrumnya dapat dilihat pada Gambar 11.
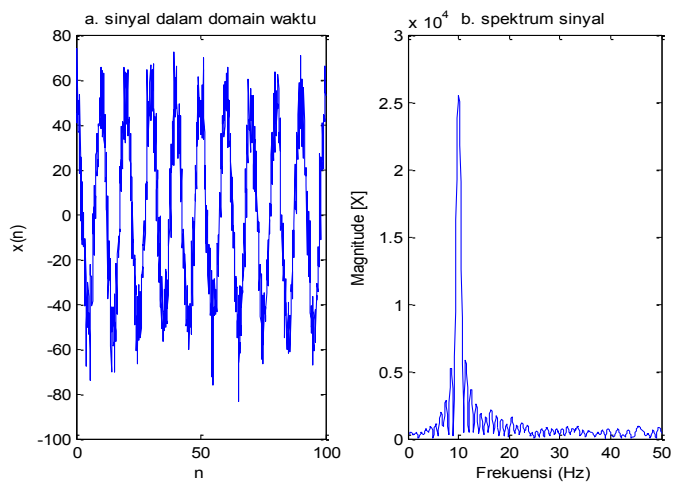

Gambar 15. Model kondisi sinyal input yang kedua dan spektrumnya.

Hasil simulasi penggunaan mother wavelet Haar, Daubechies-12, Coiflet-5 dan Symlet-8 pada $D W T$ pada aplikasi penghilangan noise dapat dilihat pada Gambar 17 dan 18. Rasio sinyal terhadap noise yang diperoleh dari hasil penggunaan mother wavelet Haar adalah 14,6692 dB, mother wavelet Daubechies-12 adalah 32,0603 dB, mother wavelet Coiflet-5 adalah 31,0005 dan mother wavelet symlet-8 adalah $32,6589 \mathrm{~dB}$.

Spektrum hasil rekontruksi dari koefisien yang tersisa dapat dilihat pada Gambar 19, 20,21,dan 22. Dari spektrum hasil rekontruksi terlihat bahwa sinyal dari sasaran yang diinginkan masih sulit untuk dideteksi, karena amplitudonya terlalu kecil, dan masih ada noise yang tersisa yang menutupi sinyal dari sasaran yang diinginkan.
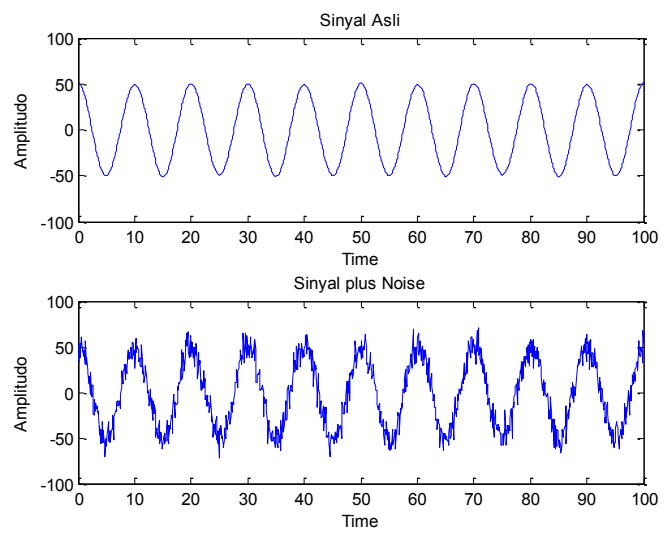

Gambar 16. Sinyal dan noise untuk model sinyal input yang kedua.
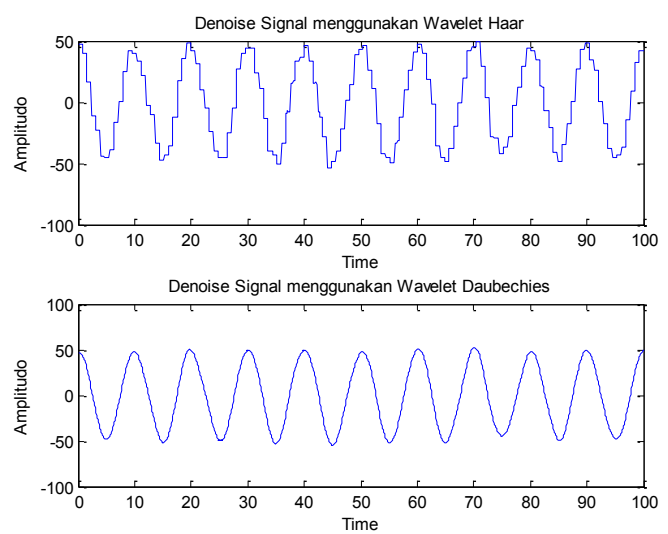

Gambar 17. Denoise Signal dengan mother wavelet Haar dan Daubechies untuk model kondisi sinyal input yang kedua.
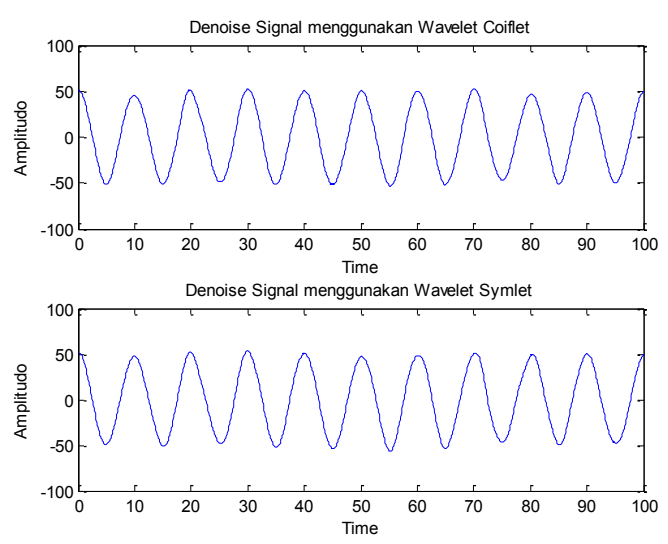

Gambar 18. Denoise Signal dengan mother wavelet Coiflet dan Symlet untuk model kondisi sinyal input yang kedua. 


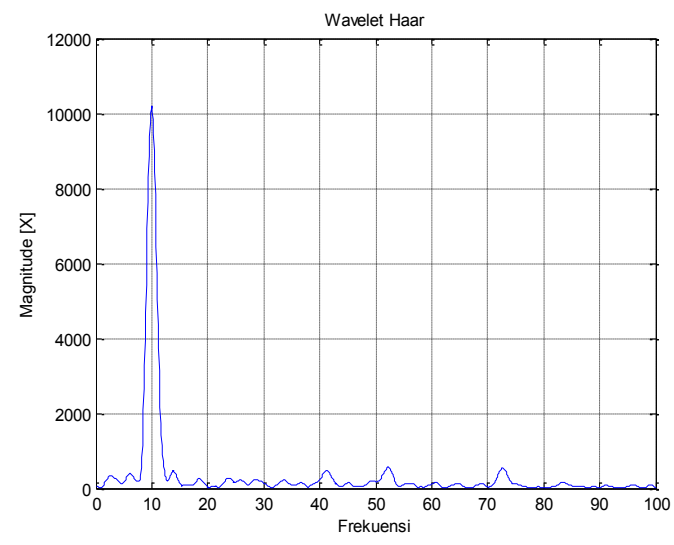

Gambar 19. Spektrum DWT dengan mother Wavelet Haar untuk model kondisi sinyal input yang kedua.

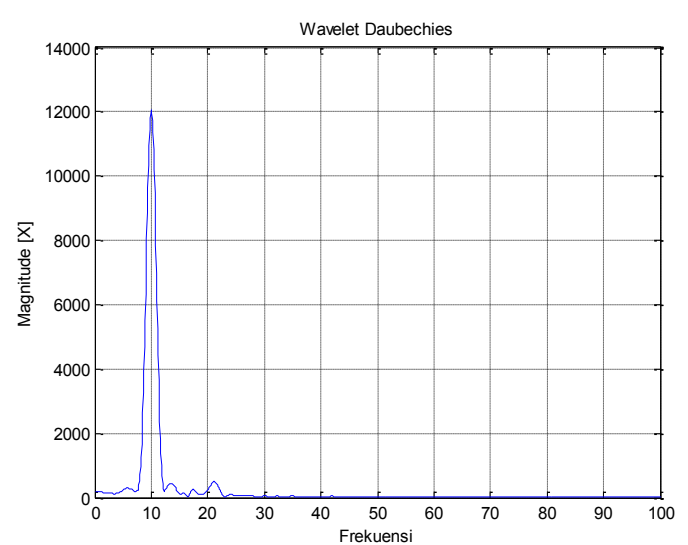

Gambar 20. Spektrum DWT dengan mother Wavelet Daubechies untuk model kondisi sinyal input yang kedua.

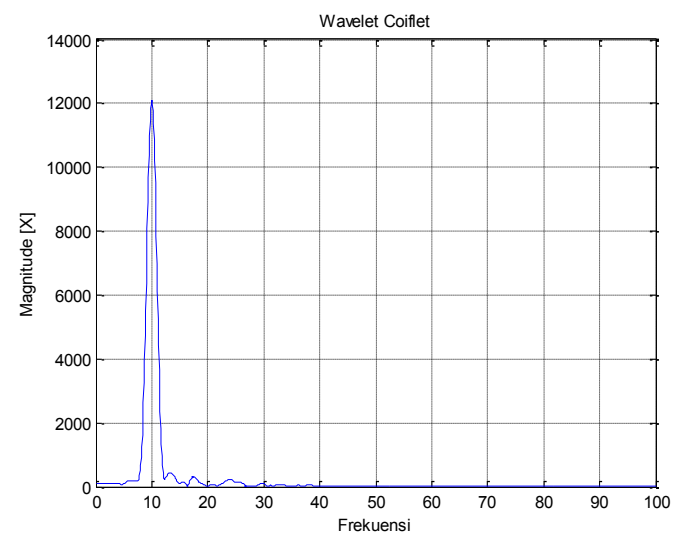

Gambar 21. Spektrum DWT dengan mother Wavelet Coiflet untuk model kondisi sinyal input yang kedua.

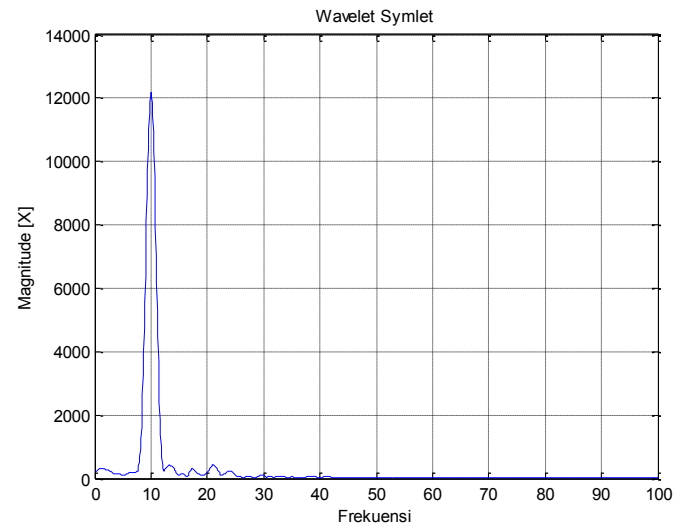

Gambar 22. Spektrum DWT dengan mother Wavelet Symlet untuk model kondisi sinyal input yang kedua.

Hasil simulasi untuk model kodisi sinyal input yang ke dua menggunakan $D C T$ dapat dilihat pada Gambar 23, 24, 25, dan 26. Dari Gambar 23 terlihat bahwa, untuk penggunaan window Rectangular, sinyal sasaran yang diinginkan tertutupi sepenuhnya oleh noise dan bocoran spektrum (spectrum leakage) dari sinyal interferensi, sehingga sinyal dari sasaran yang diinginkan sangat sulit dideteksi. Untuk penggunaan window Hamming, Hanning dan Dolph-Chebyshev, pada Gambar 24, 25 dan 26, terlihat bahwa fungsi window tidak dapat mengurangi noise, tetapi hanya dapat mengurangi bocoran spektrum. Karena noise tersebar secara merata ke dalam semua bin, dan menutupi seluruhnya sinyal sasaran yang diinginkan, sehingga sinyal dari sasaran yang diinginkan tidak dapat dideteksi.

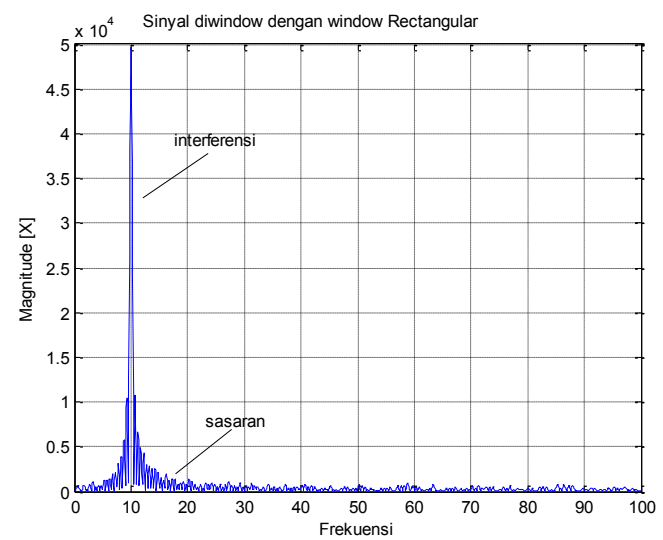

Gambar 23. Spektrum DCT dengan window Rectangular untuk model kondisi sinyal input yang kedua. 


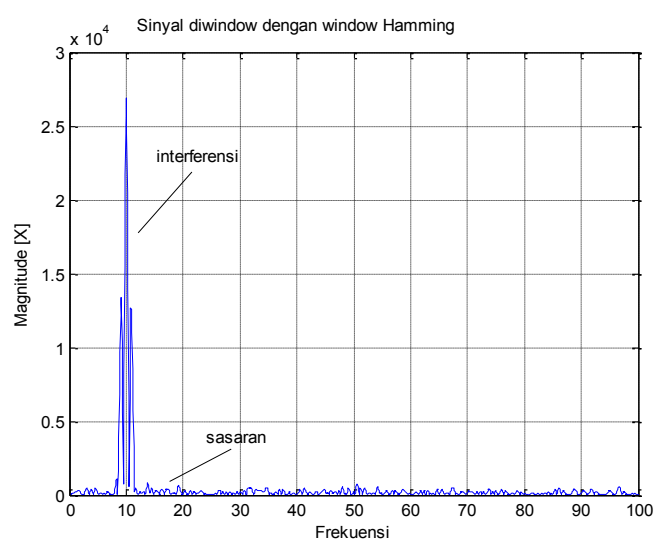

Gambar 24. Spektrum DCT dengan window Hamming untuk model kondisi sinyal input yang kedua.

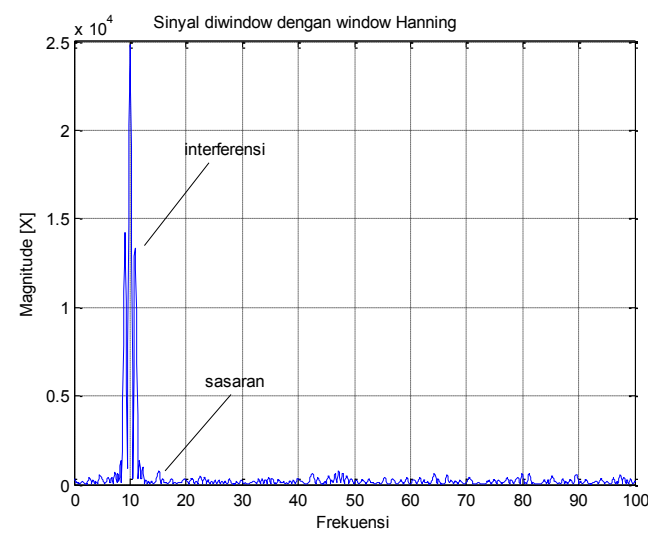

Gambar 25. Spektrum DCT dengan window Hanning untuk model kondisi sinyal input yang kedua.

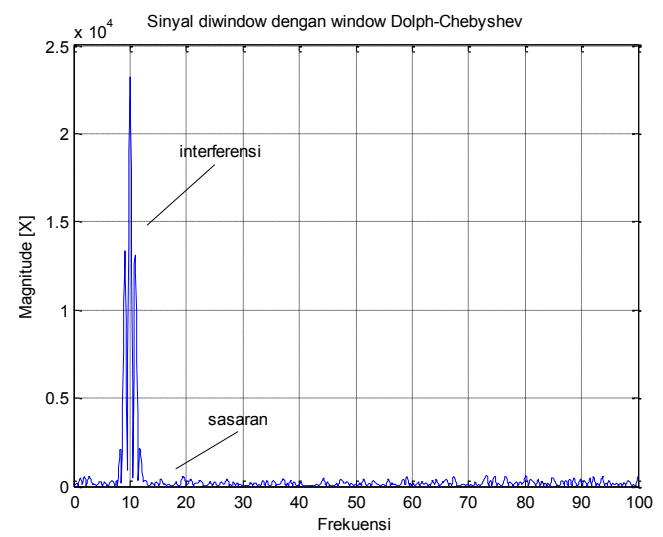

Gambar 26. Spektrum DCT dengan window Dolph-Chebyshev untuk model kondisi sinyal input yang kedua.

\section{KESIMPULAN}

Berdasarkan hasil simulasi dan analisis dalam thesis ini, dapat disimpulkan:

1. Pada pengujian mother wavelet Haar, Daubechies-12, Coiflet-5 dan Symlet 8 pada Discrete Wavelet Transform dalam memisahkan komponen-komponen frekuensi Doppler suatu sinyal pantulan yang diterima kembali oleh radar, dari hasil spektrum full recontruction diperoleh performansi yang sama untuk mother wavelet Haar, Daubechies-12, Coiflet-5 dan Symlet-8. Pada pengujian dalam menghilangkan noise suatu sinyal pantulan yang diterima kembali oleh radar, dari hasil perbandingan sinyal terhadap noise $(\mathrm{S} / \mathrm{N})$ dan spektrum rekontruksi dari koefisien yang tersisa, mother wavelet Daubechies-12 dan Symlet-8 menghasilkan performansi terbaik dan mother wavelet Haar menghasilkan performansi paling jelek. Rasio sinyal terhadap noise yang paling tinggi diperoleh dari penggunaan mother wavelet Daubechies-12 adalah 32,0603 dB. Dan untuk penggunaan mother wavelet Symlet8 diperoleh rasio sinyal terhadap noise yang paling tinggi adalah $32,6589 \mathrm{~dB}$. Dan untuk penggunaan mother wavelet Haar, rasio sinyal terhadap noise yang paling tinggi adalah 14,6692 dB.

2. Pada pengujian window Rectangular, Hamming, Hanning dan Dolph-Chebyshev pada Discrete Cosine Transform (DCT) dalam memisahkan komponen-komponen frekuensi Doppler suatu sinyal pantulan yang diterima kembali oleh radar, dari hasil spektrumnya, performansi yang paling baik diperoleh dari hasil penggunaan window Dolph-Chebyshev. Dalam menghilangkan noise, fungsi window pada Discrete Cosine Transform (DCT) tidak dapat mengurangi noise, tetapi hanya mengurangi bocoran spektrum, karena noise tersebar merata dalam semua bin.

3. Analisis sinyal pantulan yang diterima kembali oleh radar dengan menggunakan Disrete Wavelet Transform (DWT) memberikan unjuk kerja (performansi) 
yang lebih baik dibandingkan dengan menggunakan Disccrete Cosine Transform (DCT), khususnya dalam menghilangkan noise.

\section{DAFTAR PUSTAKA}

1. O. A. M. Aly, A. S. Omar, and A. Z. Elsherbeni. 2006. Detection And Localization Of RF Radar Pulses in Noise Environments using Wavelet Packet Transform and Higher Order Statistics. Progress In Electromagnetics Research. PIER 58, 301-317.

2. Ilkka Ellonen and Arto Kaarna. 2008. Chaff Clutter Filtering from Radar Data with Discrete Wavelet Transform. Radar Conference, Radar 08 IEEE. Rome.

3. Ilkka Ellonen and Arto Kaarna. 2006. Rain Clutter Filtering from Radar Data with Discrete Wavelet Transform. International Radar Symposium. Krakow, Poland. pp. 193-196.

4. Muh Taufik Setyawan. Simulasi Tapis Finite Impuls Response (FIR) dengan Discrete Cosine Transform (DCT). Semarang. Indonesia.

5. Byron Edde. 1993. Radar: Principles, Technology, Applications. Prentice-Hall.
6. Bassem R and Mahafza. 2000. Radar Systems Analysis and Design Using Matlab. Chapman \& Hall/CRC. Washington, D. C.

7. Martin Vetterli. 1992. Wavelet and Filter Banks, Theory and Design. IEEE Transaction on Signal Processing, Vol 40, no 9, September 1992. PP 2207-2232.

8. DR. W. J. Phillips, Wavelet And Filter Banks Course Notes.

9. Leon W. Couch, II. 2007. Digital And Analog Communication Systems. Sixth Edition, Prentice Hall.

10. Adrian E, Villanueva-Luna and Alberto Jaramillo-Nunez. 2011. De-Noising Audio Signals using MATLAB Wavelet Toolbox. In Tech, 10 October 2011, ISBN 978-953307-656-0.

\section{Biodata Penulis}

Raisah Hayati, Lahir di Banda Aceh pada tahun 1979. Menerima gelar sarjana di Fakultas Teknik Universitas Syiah Kuala, Darussalam-Banda Aceh pada tahun 2004. Sekarang tengah menempuh pendidikan jenjang Megister Teknik Elektro Universitas Andalas Padang. 